\title{
Characterization of alternatively spliced isoforms of AMPA receptor subunits encoding truncated receptors
}

\author{
André R. Gomes, ${ }^{\mathrm{a}, 1}$ Joana S. Ferreira, ${ }^{\mathrm{a}, 1}$ Ana V. Paternain, ${ }^{\mathrm{b}}$ Juan Lerma, \\ Carlos B. Duarte, ${ }^{\mathrm{a}}$ and Ana Luísa Carvalho ${ }^{\mathrm{a}, *}$ \\ ${ }^{a}$ Centre for Neuroscience and Cell Biology, Department of Zoology, University of Coimbra, Largo Marquês de Pombal, 3004-517 Coimbra, Portugal \\ binstituto de Neurociencias de Alicante, CSIC-UMH, 03550 Sant Joan d'Alacant, Spain
}

Received 22 June 2007; revised 11 October 2007; accepted 16 October 2007

Available online 23 October 2007

Glutamate receptors of the $\alpha$-amino-3-hydroxy-5-methyl-4-isoxazolepropionic acid (AMPA)-type play an important role in synaptic plasticity and contribute to cell death under excitotoxic conditions. AMPA receptors form heterotetramers of four homologous subunits (GluR1-4), which exist in two functionally different isoforms, flip and flop, generated by alternative splicing. We identified transcripts for alternatively spliced isoforms of AMPA receptor subunits which lack both the flip and the flop exons, in hippocampal and retinal cultures. These transcripts originate AMPA receptor subunits lacking the flip/ flop cassette, the fourth transmembrane domain and the intracellular C-terminus. Truncated GluR1 associates with full-length GluR1 and exerts a dominant negative effect, giving rise to non-functional receptors. Moreover, truncated GluR1 reaches the cell surface, but is not efficiently targeted to the synapse. Hippocampal neuronal transfection with truncated GluR1 resulted in a significant reduction in apoptotic neuronal death triggered by toxic concentrations of glutamate. Furthermore, mRNA coding for the truncated subunits is consistently detected in some regions of the brain in epileptic rats and in hippocampal neurons submitted to toxic concentrations of glutamate. The existence of truncated AMPA receptor subunits may constitute an intrinsic neuroprotective mechanism.

(C) 2007 Published by Elsevier Inc.

Keywords: Flip/flop; Dominant negative; Excitotoxicity; Neuroprotection; Synaptic targeting

\section{Introduction}

Most excitatory synapses in the central nervous system use glutamate as a neurotransmitter. Fast signaling at these synapses occurs primarily by activation of $\alpha$-amino-3-hydroxy-5-methyl-4-

\footnotetext{
* Corresponding author. Fax: +351 239480208.

E-mail address: alc@cnc.uc.pt (A.L. Carvalho).

1 These authors contributed equally to this work.

Available online on ScienceDirect (www.sciencedirect.com).
}

isoxazolepropionic acid (AMPA)-type glutamate receptors. These receptors are also implicated in specific forms of synaptic plasticity, such as long-term potentiation (LTP) and long-term depression (LTD) (Malenka and Bear, 2004), and in excitotoxicity (Kwak and Weiss, 2006).

AMPA receptors are heterotetramers of subunits GluR1-4 (Hollmann and Heinemann, 1994). mRNA coding for AMPA receptors is translated in the rough endoplasmic reticulum (RER), where receptor assembly begins (Bredt and Nicoll, 2003). The first step in assembly of AMPA receptors is the formation of dimers, through the N-terminal region of receptor subunits, followed by the dimerization of dimers into tetramers (Ayalon and Stern-Bach, 2001). AMPA receptors transit through the Golgi, where they are glycosylated into mature receptors (Bredt and Nicoll, 2003), they are subsequently targeted to the plasma membrane in a dynamically regulated manner (Gomes et al., 2003), and are specifically clustered at excitatory synapses on dendritic spines and shafts. Given that the translation of mRNA that encodes these subunits is believed to occur largely in the cell soma, the synaptic targeting of the receptors requires directed protein transport and synaptic stabilization (O'Brien et al., 1998). AMPA receptor trafficking is regulated by numerous AMPA receptor-binding proteins, depending on their subunit composition. It is widely accepted that the trafficking of AMPA-type receptors in an activity-dependent manner mediates rapid synaptic modification underlying LTP and LTD (Malinow and Malenka, 2002).

AMPA receptor subunit composition determines channel function (Ozawa et al., 1998) and trafficking to synapses (Malinow et al., 2000). All subunits have a similar domain structure, composed of a large extracellular N-terminus followed by four membrane domains (M1-M4), the second of which (M2) loops in and out of the intracellular side of the membrane and forms a cation permeable channel (Ozawa et al., 1998; Madden, 2002). The third membrane domain leads to an extracellular loop that, together with part of the amino-terminal domain (NTD), forms the glutamate binding site (S1S2) (Hollmann et al., 1994). After the fourth transmembrane domain, AMPA receptors end in an intracellular 
C-terminal segment, which contains phosphorylation sites (Carvalho et al., 2000) and multiple sites of interaction with intracellular proteins, such as PDZ domain-containing proteins of the postsynaptic density (Gomes et al., 2003). The four subunits of AMPA receptors exist in two distinct forms, flip and flop, generated by alternative splicing of the 115 base pair (bp) exons that constitute the flip/flop cassette (Sommer et al., 1990) and encode part of the extracellular segment that precedes the fourth transmembrane domain. This region is not involved directly in ligand binding but appears to modulate receptor desensitization and channel conductance (Mosbacher et al., 1994). Flop versions are more abundant in adult neurons than in the developing brain and usually desensitize more rapidly than flip versions (Monyer et al., 1991).

Alternative splicing is of major importance in generating proteomic diversity and in modulating protein activities in a temporal and spatial manner (Grabowski and Black, 2001). Approximately $40 \%$ to $60 \%$ of human genes are alternatively spliced (Modrek and Lee, 2002). In the brain, the expression profiles of splice isoforms are modified during development and as neuronal activity changes (Lipscombe, 2005). For $N$-methyl-D-aspartic acid (NMDA) receptors, a direct link between NR1 mRNA splicing, activity and synaptic homeostasis was established (Mu et al., 2003). Chronic activity blockade increases the expression of the splicing variants of NR1 with accelerated endoplasmic reticulum (ER) export, whereas the expression of other splice variants decreases. Conversely, increasing neuronal activity caused an inverse change in the expression of NR1 splice variants.

In this study, we identified an alternative splicing isoform of AMPA receptor subunits lacking both the flip/flop exons. In hippocampal and retinal neurons in culture, the transcript encoding this isoform contains a premature stop codon and gives rise to truncated subunits lacking the flip/flop cassette, the fourth transmembrane domain and the intracellular C-terminal domain. We investigated the ability of these subunits to associate with fulllength subunits and form functional receptors, and analyzed the cellular localization of AMPA receptors containing truncated subunits. We also explored the hypothesis that AMPA receptors containing truncated subunits may have a neuroprotective role in excitotoxic conditions.

\section{Results}

Identification of splice variants of AMPA receptor subunits in neuronal cultures

Total RNA isolated from rat hippocampal cultures 14 days in vitro (DIV), and from chick retinal cultures 5 DIV, was amplified by RT-PCR using primers for the AMPA receptor subunits (GluR1-4), designed to span the segment encoding the flip/flop region and part of the fourth transmembrane domain. Besides the PCR products of predicted length (666 bp for GluR1, $486 \mathrm{bp}$ for GluR2, 496 bp for GluR3 and 622 bp for GluR4), lower molecular weight products for GluR1-3 (551 bp for GluR1, $371 \mathrm{bp}$ for GluR2, and 381 bp for GluR3) were observed in hippocampal cultures (Fig. 1A shows the amplification products for GluR1) and for GluR4 (507 bp) in retinal cultures (Fig. 1B). The lower molecular weight products were originally detected among amplification products obtained using total cDNA (e.g., Fig. 1B), but were more evident in the amplification products obtained after cDNA digestion with $R s a \mathrm{I}$, which digests the abundant cDNA molecules containing the flip/flop region (e.g. Fig. 1A). These amplification products were isolated, subcloned and sequenced. Sequence analysis showed that the lower molecular weight transcripts correspond to AMPA receptor subunits lacking both the flip and flop exons (Fig. 1C). Deletion of the flip/flop exons introduces a premature stop codon and results in truncated translation products, which lack the flip/flop region, the fourth transmembrane domain and the $\mathrm{C}$-terminus of the receptor subunits (GluR $\Delta \mathrm{i} / \mathrm{o}$; Fig. 1D).

\section{Functional characteristics of truncated AMPA receptor subunits}

In order to determine whether this new splice isoform of AMPA receptor subunits is capable of forming heteromeric receptors with full-length AMPA receptor subunits, we tested for their biochemical association when overexpressed in COS7 cells, using coimmunoprecipitation assays. Using COS7 cells transfected with GluR1 and GFP-GluR1 $\triangle \mathrm{i} / \mathrm{o}$ or GluR1 and GluR1 $\Delta \mathrm{i} / \mathrm{o}$, we found that truncated AMPA receptor subunits can co-immunoprecipitate with full-length AMPA receptor subunits (Fig. 2A, middle panel) and vice-versa (Fig. 2A, right panel). To understand whether the truncated subunits form functional receptors, alone or in coexpression with full-length subunits, we evaluated currents generated by AMPA receptors containing the truncated subunits (Fig. 2B). Whole-cell currents were measured in HEK 293 cells transfected with a plasmid encoding the truncated form of GluR1 $($ GluR1 $\Delta \mathrm{i} / \mathrm{o})$, and no currents could be detected in any of the cells recorded ( $n=14$, data not shown), so we concluded that homomeric receptors of the truncated AMPA receptor subunits are not functional (Fig. 2B). However, co-expression of truncated AMPA receptor subunits with full-length constructs produced whole-cell currents with lower amplitude than those observed when fulllength receptors were expressed, therefore exerting a dominantnegative effect (Fig. 2B). We observed the same decrease in the amplitude of whole-cell currents produced by GluR2- and GluR3containing receptors when co-expressed with GluR1 $\Delta \mathrm{i} / \mathrm{o}$ (data not shown). In order to test whether the detected currents in cells cotransfected with GluR1 $\Delta \mathrm{i} / \mathrm{o}$ and the full-length subunits were due to the response of heteromeric receptors rather than to homomeric full length receptors, we electrophysiologically tagged GluR $1 \Delta \mathrm{i} / \mathrm{o}$ by replacing the glutamine residue $(\mathrm{Q})$ at the pore forming region of the receptor for an arginine (R). This replacement occurs naturally by RNA editing in GluR2, and changes the rectification characteristics of the currents (Verdoorn et al., 1991). The currents recorded in cells co-transfected with GluR1 $\Delta \mathrm{i} / \mathrm{o}(\mathrm{R})$ and GluR1 had the same rectification index as the currents recorded in cells transfected with GluR1 but presented a significant lower amplitude, indicating that the observed currents are generated by a population of homomeric GluR1 receptors and that heteromeric receptors containing the truncated AMPA receptor subunits are not functional (Fig. 2C).

To understand how the truncated forms of AMPA receptor subunits exert their dominant negative effect, we tested their capacity to bind AMPA, and whether in heteromeric complexes they interfere with the capacity of full-length AMPA receptor subunits to bind AMPA (Fig. 3). Binding studies with $\left[{ }^{3} \mathrm{H}\right] \mathrm{AMPA}$ in extracts from HEK 293 cells transfected with the truncated form of GluR1 (GluR1 $\Delta \mathrm{i} / \mathrm{o})$ showed that GluR1 $\mathrm{i} / \mathrm{o}$ subunits do not form binding sites for AMPA. However, when the truncated form was co-transfected with full-length GluR1, the $B_{\max }$ was not affected, indicating the capacity of heteromeric receptors to bind the ligand. 
A

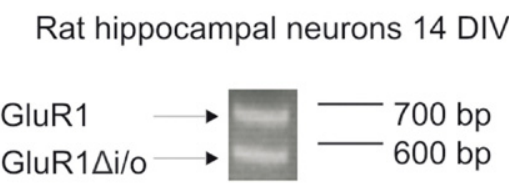

B

Chick retinal neurons 5 DIV

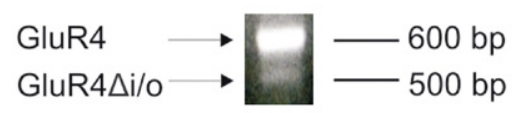

D

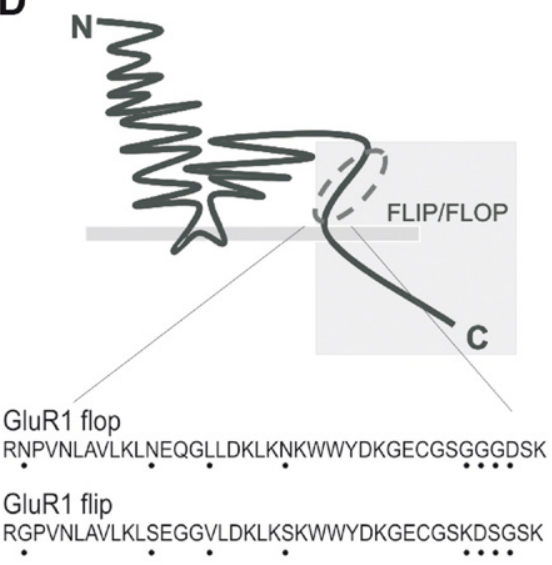

C GluR1 gene

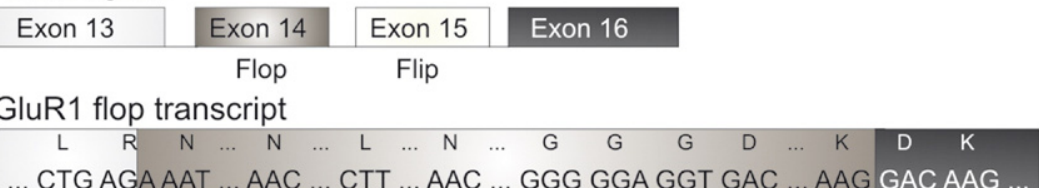

GluR1 flip transcript

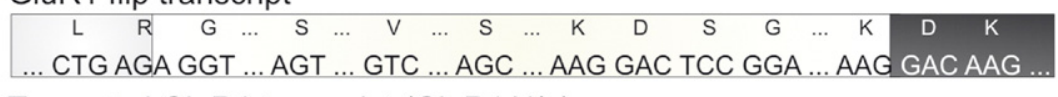

Truncated GluR1 transcript (GluR1 $\triangle \mathrm{i} / \mathrm{o}$ )

\begin{tabular}{cccccccc}
\hline L & $R$ & T & R & P & A & L & STOP \\
... CTG & AGG & ACA ACA A & CCA & GCG & CTT & TGA
\end{tabular}

Fig. 1. Identification of splice variants of AMPA receptor subunits in rat hippocampal and chicken retina cultures. (A) RT-PCR products of AMPA receptor subunit GluR1, amplified from hippocampal cultures, 14 DIV. Amplification was performed using primers that span the flip/flop region and part of TM4. In the upper panel, the cDNA molecules containing the flip/flop exons were partially digested with RsaI previous to amplification in order to facilitate the amplification of the variant lacking the flip/flop exons (GluR $\Delta \mathrm{i} / \mathrm{o}$ ). (B) RT-PCR amplification of GluR4 subunit from chick retinal cultures, 5 DIV, using primers that span the flip/flop region and part of TM4. (C) Comparison of the amplified nucleotide sequences encoding full-length and truncated isoforms of AMPA receptor GluR1, and of the corresponding translation products. The 5 amino acid sequence originated by the frameshift, before the stop codon, is indicated. Corresponding sequences for the other AMPA receptor subunits are: KRPVPSV (GluR2), TRPVL (GluR3) and TRRVP (GluR4). (D) Schematic representation of truncated isoforms of AMPA receptor subunit, lacking the flip/flop cassette, the fourth transmembrane domain and the C-terminus (box).

\section{Cell surface expression and subcellular localization of truncated GluR1}

Because the C-terminal region of AMPA receptor subunits contains multiple sites of interaction with cytosolic proteins involved in AMPA receptor trafficking, we studied the cell surface and subcellular localization of AMPA receptor containing truncated subunits. The observation that the currents recorded from cells co-transfected with full-length and truncated subunits are due to the activity of receptors that do not incorporate truncated subunits, and that mixed receptors do not produce currents, led to the hypothesis that incorporation of truncated subunits in receptor complexes may result in intracellular sequestration of full-length subunits. In order to investigate the trafficking of truncated AMPA receptor subunits to the cell surface, we transfected HEK 293 cells with full-length GluR1, or truncated GluR1, tagged with GFP at the N-terminus (GFP-GluR1 $\Delta \mathrm{i} / \mathrm{o})$, and COS7 cells with GluR1 and GluR1 $\Delta \mathrm{i} / \mathrm{o}$. Cell surface proteins were biotinylated, and purified by affinity chromatography. Western blot analysis of the purified fraction revealed that truncated GluR1 subunits do reach the cell surface, by themselves and when co-transfected with GluR1, to a similar extent as full-length GluR1 (Figs. 4A, B). These results are similar for both constructs, with or without GFP, and do not support the hypothesis that the truncated subunits prevent the fulllength subunits from reaching the plasma membrane. As a complementary approach to the biotinylation experiments, we transfected COS7 cells with GluR 1 or GluR $1 \Delta \mathrm{i} / \mathrm{o}$ and labeled them in vivo with an anti-GluR1 N-terminal antibody, before fixation, to visualize superficial receptors. The results are in agreement with the previous observations, showing superficial expression of truncated GluR1 (Fig. 4C). We also observed cell surface expression of truncated AMPA receptor isoforms in cultured hippocampal neurons, by transfecting 14 DIV cultures with full-length and truncated subunits, GFP-tagged, and immunolabeling with an antiGFP antibody in vivo (Fig. 4D). It is important to notice that although both GFP-GluR1 and GFP-GluR1 $\Delta \mathrm{i} / \mathrm{o}$ reach the neuronal surface, the full-length GluR1 shows a punctuate distribution throughout the dendrites, whereas GluR $1 \Delta \mathrm{i} / \mathrm{o}$ shows a diffuse distribution in the dendrites (Fig. 4E). To investigate the subcellular localization of AMPA receptors containing the truncated GluR1 subunits, we transiently transfected hippocampal neurons (14 DIV) with full-length or truncated GluR1, tagged with GFP at the Nterminus. These cultures were labeled for PSD 95, a synaptic marker, and were imaged by fluorescence microscopy (Fig. 4E). The 
A

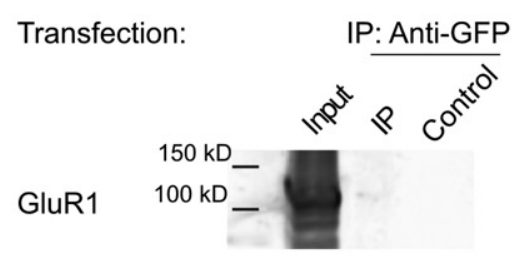

WB: Anti-GluR1 C-term

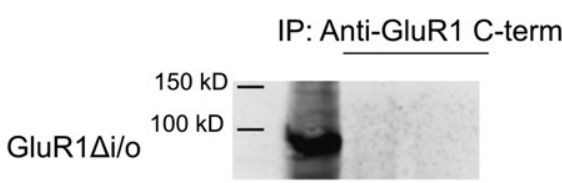

$\begin{array}{cc}\text { WB: Anti-GluR1 N-term } \\ \text { GFP- } & 150 \mathrm{kD}- \\ \text { GluR1 }- & \\ 100 \mathrm{kD}- & \end{array}$

WB: Anti-GFP

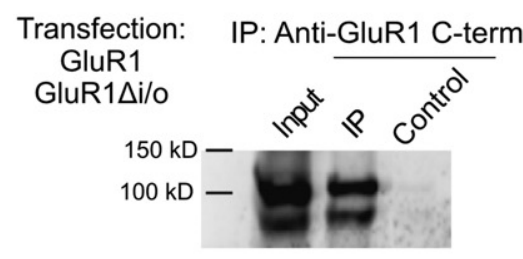

WB: Anti-GluR1 N-term

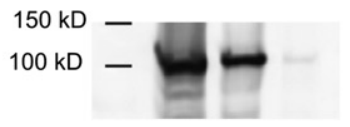

WB: Anti-GluR1 C-term

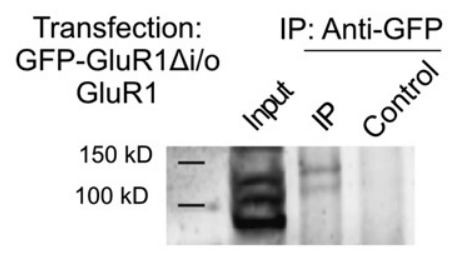

WB: Anti-GluR1 N-term

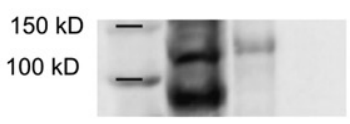

WB: Anti-GFP

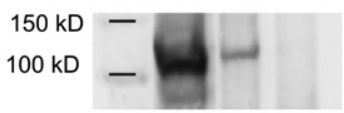

WB: Anti-GluR1 C-term

B

GluR1

GluR1+GluR1 $\Delta \mathrm{i} / \mathrm{o}(1: 1)$

GluR1+GluR1 $\Delta$ i/o (1:3)

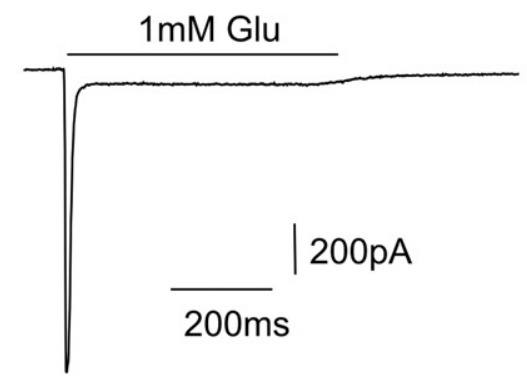

C

GluR1

$(-70 ;-50 ;-30 ;-10 ;+10 ;+30 ;+50 \mathrm{mV})$

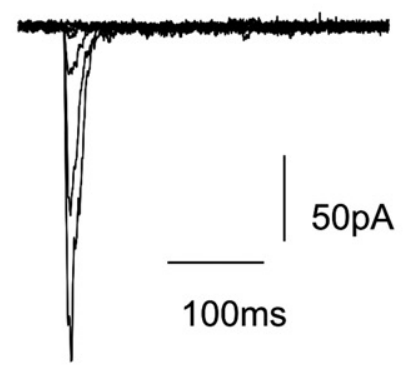

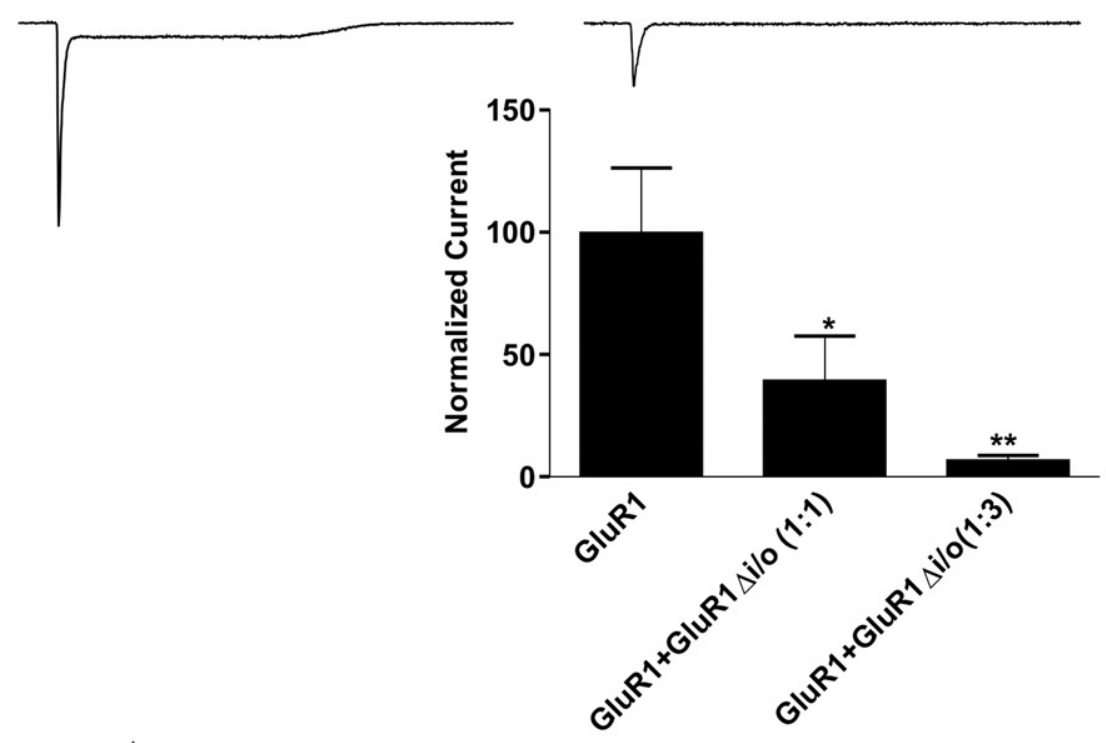

GluR1 + GluR1R $(-70 ;-50 ;-30 ;-10 ;+10 ;+30 ;+50 \mathrm{mV})$
GluR1 + GluR1 $\triangle \mathrm{i} / \mathrm{oR}$ $(-70 ;-50 ;-30 ;-10 ;+10 ;+30$; +50mV) 


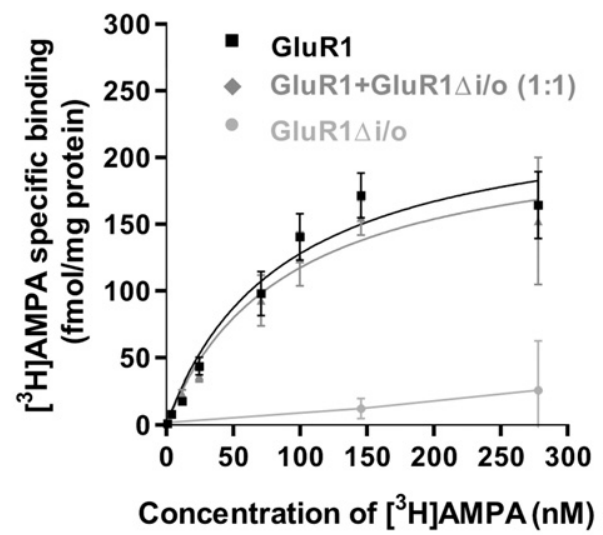

\begin{tabular}{|l|cc|}
\hline & GluR1 & GluR1+GluR1Di/o \\
\hline $\mathbf{B}_{\text {MAX }}(\mathrm{fmol} / \mathrm{mg})$ & 239.0 & 204.5 \\
$\mathrm{~K}_{\mathrm{D}}(\mathrm{nM})$ & 76.87 & 76.70 \\
\hline
\end{tabular}

Fig. 3. Saturation binding curve of $\left.{ }^{3} \mathrm{H}\right] \mathrm{AMPA}$ in membranes of HEK 293 cells expressing GluR1, GluR1+GluR1 $\Delta \mathrm{i} / \mathrm{o}(1: 1)$ or GluR1 $\Delta \mathrm{i} / \mathrm{o}$. HEK 293 cells were transfected and cell membranes were isolated. The curves represent specific binding of $\left[{ }^{3} \mathrm{H}\right] \mathrm{AMPA}$, calculated as the difference between the total binding and the nondisplaceable binding, as a function of the concentration of free $\left[{ }^{3} \mathrm{H}\right] \mathrm{AMPA}$. There is no statistically significant difference between the curves for cells expressing GluR1 and expressing GluR1+GluR1 $\Delta \mathrm{i} / \mathrm{o}(p=0.18) . B_{\mathrm{MAX}}$ and $K_{\mathrm{D}}$ were determined using nonlinear regression followed by one site binding hyperbola equation. Data are relative to three independent experiments done in triplicate. The recombinant protein levels were found to be similar in all conditions by Western blot analysis (not shown).

distribution of full-length GluR1 was mostly dendritic, with a punctate labeling which co-localizes with PSD-95, whereas truncated GluR1 showed little co-localization with the synaptic marker (Fig. 4E).

\section{Truncated GluR1 protects against excitotoxic insults}

The electrophysiology data showed that truncated forms of AMPA receptor subunits produce a dominant-negative effect when incorporated in AMPA receptors (Fig. 2B). This observation led us to investigate whether these truncated subunits could have a protective effect against excitotoxic insults. To test this hypothesis we incubated 6 DIV hippocampal cultures transfected at 5 DIV with GFP, with GFP-GluR1, with GFP-GluR1 $\Delta \mathrm{i} / \mathrm{o}$, or co-transfected with GFP-GluR1 and GFP-GluR1 $\Delta \mathrm{i} / \mathrm{o}$, with $125 \mu \mathrm{M}$ of glutamate for 20 minutes. Four independent hippocampal cultures were analyzed, and, for each culture, 120 to 150 transfected cells were scored for each condition. Apoptotic death of transfected cells was assessed by analyzing nuclear morphology, 14 hours after the excitotoxic insult, using Hoechst 33342 (Fig. 5B). Apoptotic morphology is typically characterized by chromatin condensation and loss of neurites. Among GFP-transfected cells, approximately $16 \% \pm 7 \%$ were found to be apoptotic in glutamate-treated cultures. This was taken as the control condition ( $100 \%$ cell death) and cell death in other conditions was normalized to cell death among GFP-transfected cells (Fig. 5A). Transfection of hippocampal neurons with GluR1 $\Delta \mathrm{i} / \mathrm{o}$ alone did not significantly alter apoptotic cell death in response to glutamate $(13 \% \pm 4$, among transfected cells). However, among the neurons co-transfected with GFP-GluR1 and GFP-GluR1 $\Delta \mathrm{i} / \mathrm{o}$, there was a significantly smaller proportion of apoptotic cells $(24 \% \pm 13$, among transfected cells) than among neurons transfected with GFPGluR1 only $(41 \% \pm 14$, among transfected cells; $P<0.05$; Fig. 5A) in the glutamate-treated preparations. These results suggest that the truncated isoform of GluR1 confers protection against the excitotoxic insult when it hetero-oligomerizes with full-length GluR1.

\section{Expression of the transcripts for truncated AMPA receptor subunits} in conditions of excitotoxicity and in epileptic rats

Because our results support the hypothesis that AMPA receptors containing truncated subunits may have a neuroprotective role in excitotoxic conditions, we investigated the circumstances under which the expression of truncated forms of AMPA receptor subunits would be increased. We amplified the transcripts for AMPA receptor subunits from total RNA isolated from hippocampal cultures 14 DIV, 4 hours after these cells were incubated with $150 \mu \mathrm{M}$ of glutamate for $20 \mathrm{~min}$ (an insult that causes excitotoxic neuronal damage-not shown). We consistently detected the expression of the transcript for the truncated form of AMPA receptor subunit GluR1 (Fig. 5C) by PCR from nondigested cDNA samples obtained from RNA isolated from glutamate-treated hippocampal neurons (the transcript encoding truncated GluR1 was clearly detected even without previous digestion with RsaI of the full-length cDNA molecules). Taking

Fig. 2. GluR1 $\Delta \mathrm{i} / \mathrm{o}$ acts as a dominant negative when co-expressed with full-length GluR1. (A) Co-immunoprecipitation of GluR1 $\Delta \mathrm{i} / \mathrm{o}$ and GluR1. Left column: COS7 cells were transfected with GluR1, GluR1 $\Delta \mathrm{i} / \mathrm{o}$ or GFP-GluR1 $\Delta \mathrm{i} / \mathrm{o}$ and immunoprecipitation was performed with an anti-GFP antibody (for GluR1 transfected cells) or with an anti-GluR1 C-terminus antibody (for GluR1 $\Delta \mathrm{i} / \mathrm{o}$ or GFP-GluR1 $\Delta \mathrm{i} / \mathrm{o}$ transfected cells). Middle column: Extracts from cells cotransfected with GluR1 and GluR1 $1 \mathrm{i} / \mathrm{o}$ were used for immunoprecipitation with an anti-GluR1 C-terminus antibody. Right column: COS7 cells were cotransfected with GFP-GluR1 $\Delta \mathrm{i} / \mathrm{o}$ and GluR1 and an anti-GFP antibody was used in the immunoprecipitation assay. Immunoprecipitated proteins were subject to Western blot analysis, as indicated, and a bead control was performed for all cell extracts (right lane of every panel). (B) Whole-cell currents of HEK 293 cells measured at $-60 \mathrm{mV}$. Cells expressing growing amounts of GluR1 $\Delta \mathrm{i} / \mathrm{o}$ and a constant amount of GluR1 were stimulated with $1 \mathrm{mM}$ glutamate. Sister HEK cells were transfected with GluR1 or GluR1+GluR1 $\Delta \mathrm{i} / \mathrm{o}$. Glutamate-evoked currents were measured in parallel. The amplitude of glutamate-induced currents in GluR $1+$ GluR $1 \Delta \mathrm{i} / \mathrm{o}$ transfected cells was expressed as a fraction of the responses observed in GluR1 transfections, which were taken as $100 \%$. Data are presented as average \pm S.E.M. for $n=16$ (GluR1 transfection), $n=13$ (GluR1+GluR1 $\Delta \mathrm{i} / \mathrm{o}(1: 1)$ co-transfection), $n=6$ (GluR1+GluR1 $\Delta \mathrm{i} / \mathrm{o}(1: 3)$ co-transfection); statistical analysis was performed using one-way ANOVA followed by Bonferroni's Multiple Comparison Test: ${ }^{*} p<0.05,{ }^{* *} p<0.01$. (C) Non-functional heteromeric GluR1-GluR1 $\Delta \mathrm{i} / \mathrm{o}$ receptors. Whole-cell currents of HEK 293 cells transfected with GluR1, GluR1+GluR1R and GluR1+GluR1 $\Delta \mathrm{i} / \mathrm{oR}$. The Q/R mutation, replacing a glutamine residue $(\mathrm{Q})$ at the pore-forming region of the receptor for an arginine $(\mathrm{R})$ (occurs naturally by RNA editing in GluR2), changes the rectification characteristics of the currents. The fact that GluR1 + GluR1 $\Delta \mathrm{i} / \mathrm{oR}$ does not have currents at positive potentials indicates that the observed currents at negative potentials are generated by a population of homomeric GluR1 receptors and that heteromeric receptors containing the truncated AMPA receptor subunits are not functional. 
these results into account, we investigated the expression of truncated forms of AMPA receptor subunits in the brain of epileptic rats, as epilepsy is characterized by increased neuronal activity (Fujikawa, 2005). We isolated total RNA from several brain regions of kainate-induced epileptic rats $24 \mathrm{~h}$ after injection of kainate. AMPA receptor subunits were amplified by RT-PCR and lower molecular weight PCR products were isolated, subcloned and sequenced. We detected the expression of the transcripts for truncated GluR3 in the cortex and hippocampus of epileptic rats by PCR from undigested cDNA samples, whereas these transcripts were not detected in the brain of control animals (Fig. 5D).

\section{Discussion}

The alternative splicing of AMPA receptor subunits at the flip/ flop exons is well known and the flip and flop isoforms are well characterized, but the mechanism of regulation that chooses the splice sites is still intriguing. We identified, by RT-PCR, a new isoform of AMPA receptor subunits in hippocampal (Fig. 1A) and retinal cultures (Fig. 1B), which lacks the flip/flop exons. The removal of the flip/flop cassette alters the reading frame and gives rise to a premature stop codon (Fig. 1C). These transcripts encode truncated subunits lacking the fourth transmembrane domain and the intracellular C-terminus (Fig. 1D), weighting about $16 \mathrm{kDa}$
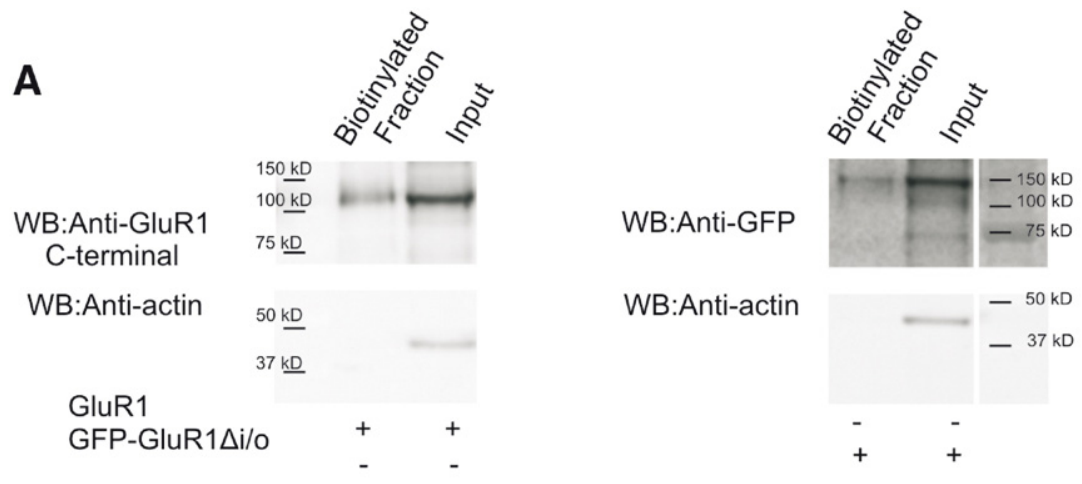

B
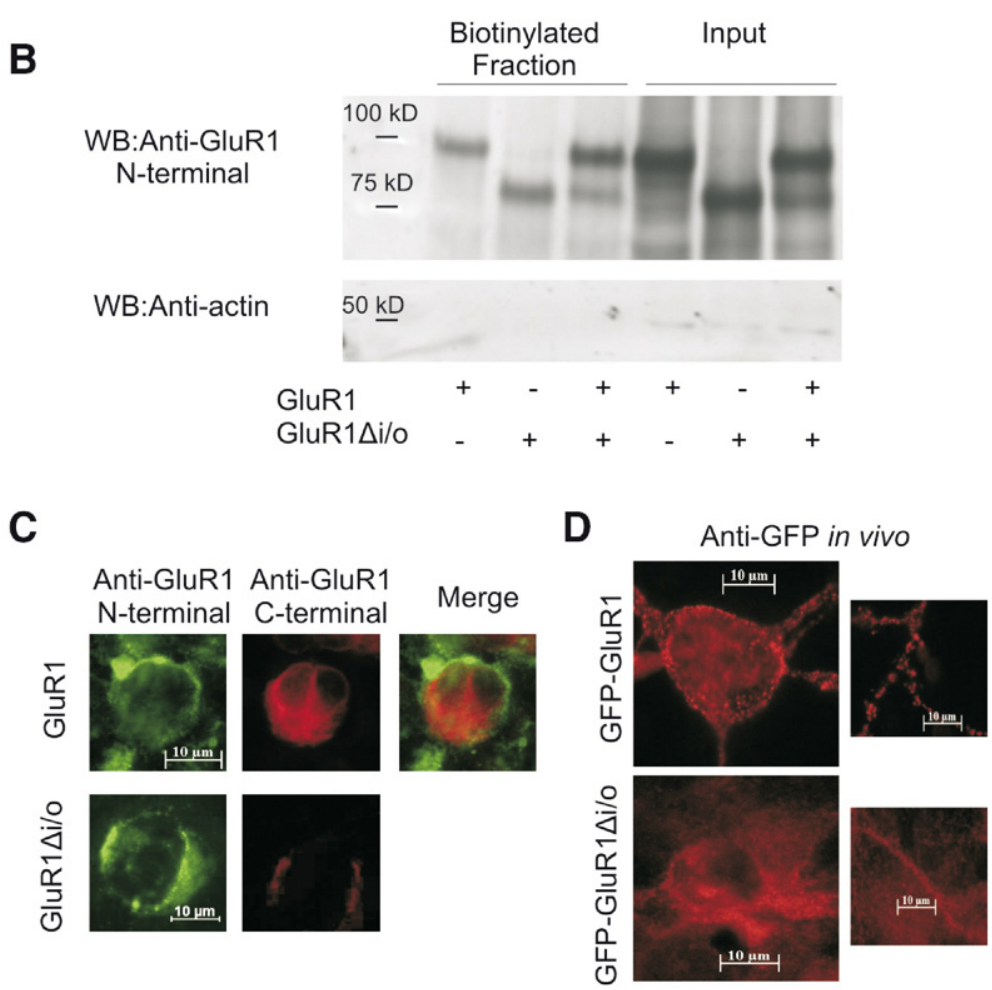

Fig. 4. Cell surface expression and subcellular localization of AMPA receptors containing truncated GluR1. (A) Biotinylated cell surface proteins were purified from HEK 293 cells, transfected with GluR1 and GFP-GluR1 $\Delta \mathrm{i} / \mathrm{o}$, and analyzed by Western blot with anti-GFP antibody. Additionally, cell surface proteins were purified from COS7 cells expressing both GluR1 and GluR1 $\Delta \mathrm{i} / \mathrm{o}$, and probed with an anti-GluR1 N-terminal antibody (B). (C) Surface staining (in vivo) of GluR1 and GluR1 $\Delta \mathrm{i} / \mathrm{o}$ with anti-GluR1 N-terminal antibody, and total staining of GluR1 with anti-GluR1 C-terminal antibody in transfected COS7 cells. (D) Immunofluorescence staining in vivo with anti-GFP antibody of cell surface receptors in hippocampal neurons (18 DIV), transfected at 14 DIV with GFP-GluR1 and GFP-GluR1 $\Delta \mathrm{i} / \mathrm{o}$. (E) Double immunostaining of GFP and PSD 95 in permeabilized hippocampal neurons transfected at 14 DIV with GFP-GluR1 and/or GFP-GluR1 $\Delta \mathrm{i} / \mathrm{o}$. Merged images of labeling with anti-GFP and anti-PSD 95 antibodies show co-localization of the full-length subunit, but not of the truncated isoform, with the synaptic marker. The lower panel shows high-magnification images of the boxed regions of the images in the upper panel. 
E GFP-GluR1 GFP-GIuR1 $\triangle \mathrm{i} / \mathrm{o}$

GluR1 + GFP-GluR1 $1 \mathrm{i} / \mathrm{o}$
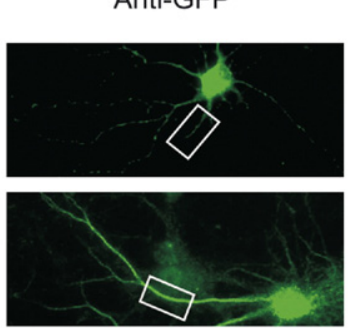

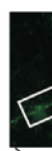
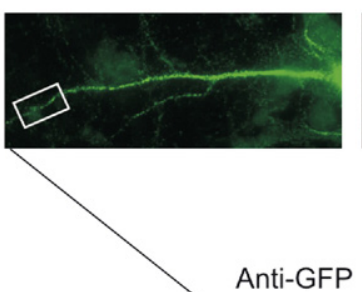

GFP-GluR1

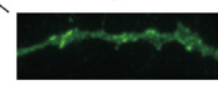

GFP-GluR1 $\triangle \mathrm{i} / \mathrm{o}$

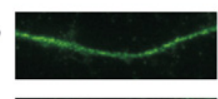

GluR1 + GFP-GluR1 $\Delta \mathrm{i} / 0$

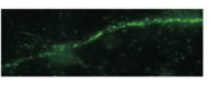

Anti-PSD 95
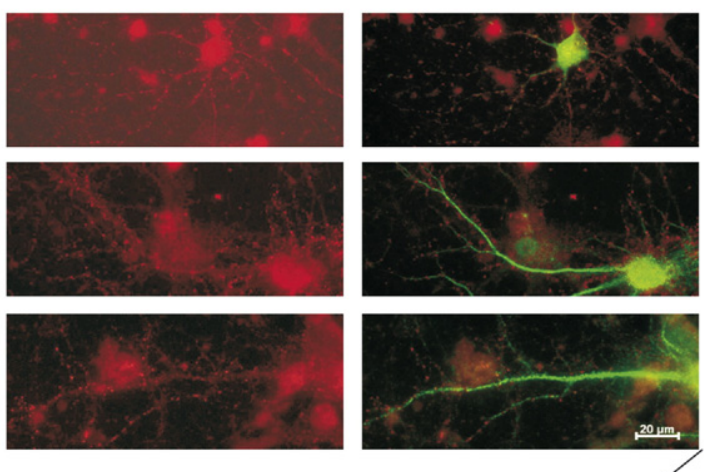

Fig. 4 (continued).

less. A previous study reported the existence of transcripts coding for truncated forms of the kainate receptor subunit GluR6 (Barbon et al., 2001), and Ravindranathan and colleagues identified three isoforms of GluR4 in chick that can be alternatively spliced and, if expressed, may encode receptors with a shorter C-terminal domain than GluR4 (Ravindranathan et al., 1997). However, the functional characteristics of these splice isoforms were not explored.

The levels of expression of the transcripts encoding the truncated AMPA receptor splice isoforms that we detected are low, and we could not detect truncated GluR1 protein in cultured neurons or in brain extracts, using an antibody against the N-terminus of the protein. However, we do not have evidences for nonsense-mediated mRNA decay (NMD) of the transcripts that lack the flip/flop exons because incubation of hippocampal neurons in culture with emetine, a protein synthesis blocker, did not increase the expression of these transcripts (data not shown). NMD ensures rapid degradation of aberrant mRNAs through a mechanism that depends on protein synthesis (Conti and Izaurralde, 2005). If this mechanism was at work for the transcripts lacking the flip/flop exons, their levels should increase upon blockade of translation.

Truncated AMPA receptor subunits heteroligomerize with fulllength subunits (Fig. 2A). However, truncated subunits cannot form homomeric or heteromeric functional receptors (Figs. 2B, C). Furthermore, truncated AMPA receptor subunits do not bind AMPA (Fig. 3). The ligand-binding domain of AMPA receptor is split into S1 and S2 subdomains by transmembrane segments. When the ligand binds to the receptor, conformational changes are transduced to the transmembrane segments to open the channel's gate (Greger et al., 2006). The truncated subunits do not have an intact S2 region, which probably impairs the exposure of the amino acids responsible for the establishment of interactions between the receptor and the ligand. This could explain why heteromeric receptors are non-functional but truncated subunits do not interfere with ligand binding of full-length subunits. We cannot exclude that the oligomerization between truncated and full-length subunits can only lead to the formation of dimers through the $\mathrm{N}$-terminal domains (Leuschner and Hoch, 1999; Ayalon and Stern-Bach, 2001; Wells et al., 2001). However, the fact that truncated subunits can oligomerize with full-length AMPA receptor subunits in nonfunctional receptors, sequestrating these subunits and consequently decreasing the available functional AMPA receptors, can explain the dominant negative effect of truncated AMPA receptor subunits.

Many studies focus on mechanisms of AMPA receptor trafficking mediated by protein partners (reviewed by Bredt and Nicoll, 2003), and most AMPA receptor-interacting proteins identified so far bind to the C-terminal tails of AMPA receptor subunits (Luscher et al., 2000; Bredt and Nicoll, 2003). Surprisingly, we observed using different approaches that AMPA receptors containing truncated subunits reach the cell surface (Fig. 4). However, although the superficial labeling in hippocampal neurons transfected with full-length GluR1 was punctated throughout the dendrites, neurons transfected with GluR $1 \Delta \mathrm{i} / \mathrm{o}$ had a more diffuse labeling that was mostly accumulated in the cell body (Fig. 4D). Although the C-terminus has several sites of interaction with proteins involved in the receptor traffic to the cell membrane (Bredt and Nicoll, 2003), it does not seem to be essential for this traffic to occur. The C-terminus fragment of GluR1 AMPA receptor subunit proximal to the membrane has been related to the dendritic sorting in neurons (Ruberti and Dotti, 2000). Therefore, to investigate the localization of AMPA receptors containing truncated GluR1 subunits, we double-immunolabeled hippocampal neurons transfected with GFP-GluR1 or GFP-GluR1 $\Delta \mathrm{i} / \mathrm{o}$, with anti-GFP and antiPSD 95 (Fig. 4E). Merged images show that only AMPA receptors containing full-length GluR1 subunits reach the synapses, whereas AMPA receptors containing truncated GluR1 subunits fail to traffic 
to the synapse. Co-transfection with GluR1 does not rescue truncated receptors to reach the synapse. These results indicate that C-terminus has a crucial role on the synaptic targeting of GluR1, probably by interacting with intracellular proteins, like Protein 4.1, that in association with SAP 97 has been suggested to regulate synaptic localization of GluR1 (Rumbaugh et al., 2003).
The dominant-negative functional effect that we observed for the truncated AMPA receptor subunits led us to speculate about a possible neuroprotective role of these receptors in excitotoxic situations. Their insertion at the plasma membrane, and the formation of non-functional heteromeric complexes with fulllength AMPA receptor subunits, diminishing the amount of full-

A

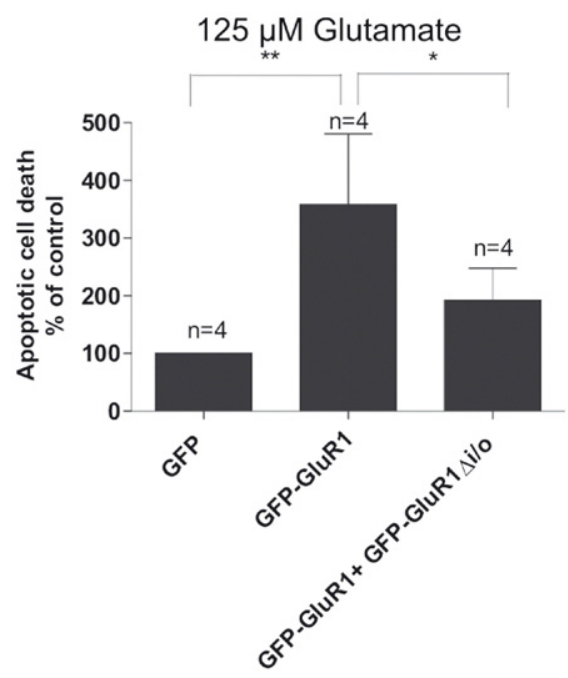

B

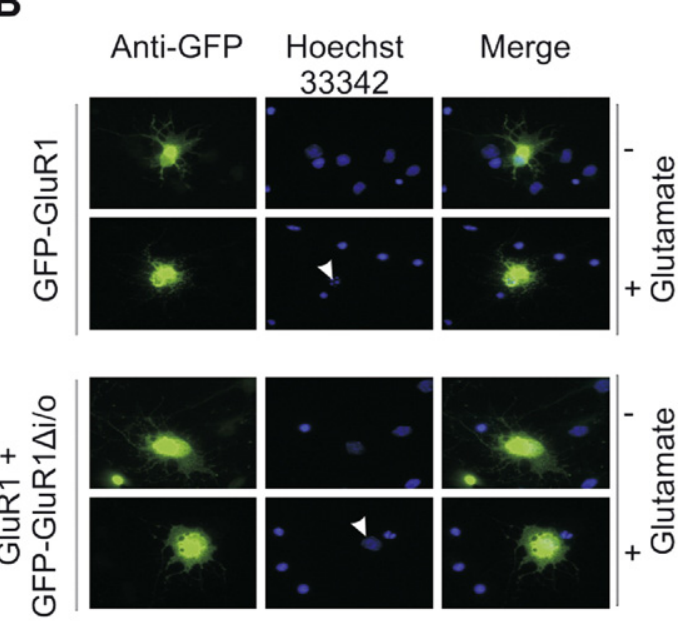

C

\&
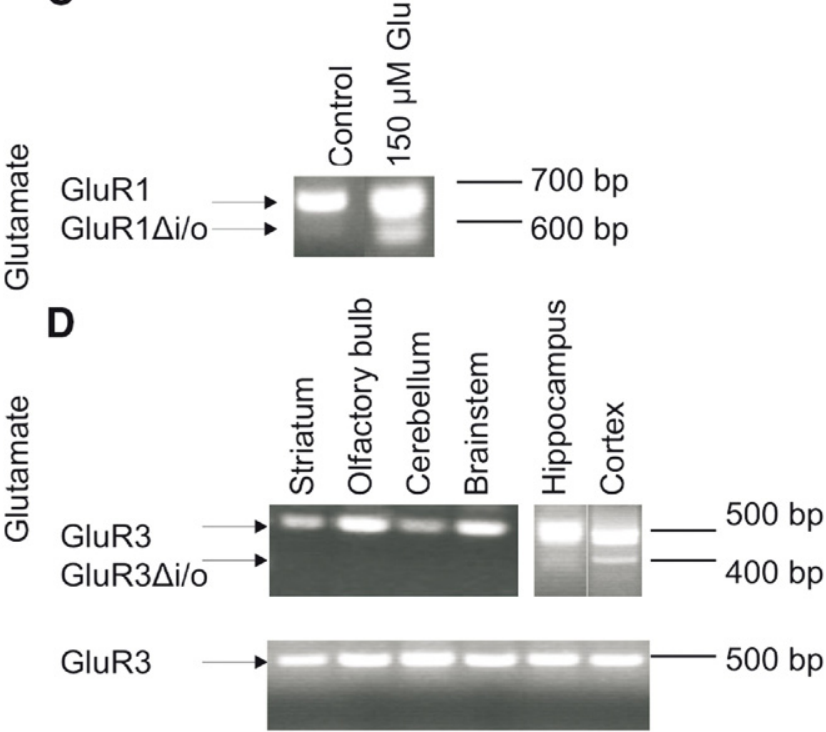

Fig. 5. Truncated isoforms of AMPA receptor subunits may be associated with neuronal protection against excitotoxic stimuli and increased neuronal activity. (A) Hippocampal neurons transfected at 5 DIV with GFP-GluR1 and GFP-GluR1 $\Delta \mathrm{i} / \mathrm{o}$ were incubated at 6 DIV with glutamate $(125 \mu \mathrm{M})$, fixed and immunolabeled with anti-GFP antibody, $14 \mathrm{~h}$ later. The viability of GFP-expressing cells was evaluated by fluorescence microscopy using the fluorescent dye Hoechst 33342. Data are presented as average \pm S.E.M. of four experiments, performed in independent preparations, and are expressed as a percentage of cell death observed in hippocampal neurons transfected with GFP alone (taken as 100\%). Statistical analysis was performed by one-way ANOVA followed by Bonferroni's Multiple Comparison Test: ** $p<0.01$ for GFP-GluR1 versus GFP, when stimulated with glutamate; ${ }^{*} p<0.05$ for GFP-GluR1 versus GFP and GFPGluR1+GFP-GluR1 $\Delta \mathrm{i} / \mathrm{o}$ versus GFP-GluR1, in control conditions, and for GFP-GluR1 + GFP-GluR1 $\Delta \mathrm{i} / \mathrm{o}$ versus GFP-GluR1, when stimulated with glutamate. (B) Nuclear morphology of hippocampal neurons 7 DIV transfected with GFP-GluR1 and co-transfected with GFP-GluR1 and GFP-GluR1 $\Delta \mathrm{i} / \mathrm{o}$, labeled with anti-GFP, in the presence or in the absence of the glutamate stimulus (white arrows, transfected cells). (C) Expression of truncated AMPA receptor subunit GluR1 in hippocampal cultures stimulated at 14 DIV with glutamate $(150 \mu \mathrm{M})$ for 20 min. Total RNA was extracted 4 h later, RT-PCR was performed using nondigested cDNA samples and the amplification products were analyzed in an agarose gel, isolated and sequenced. (D) Expression of AMPA receptor subunit GluR3 in the cortex and in the hippocampus of epileptic rats, sacrificed $24 \mathrm{~h}$ after kainate injection. Products were amplified by PCR of cDNA obtained from RNA isolated from the hippocampus and the cortex of epileptic rats, without digestion with RsaI to eliminate full-length transcripts. In the case of cDNA samples from the striatum, olfactory bulb, cerebellum, and brainstem, the samples were digested with RsaI to eliminate the full-length transcripts before PCR amplification. The bottom panel shows the RT-PCR products obtained using RNA isolated from control rats. 
length subunits available to form functional receptors, could balance the availability of functional AMPA receptors, which overactivation is associated with apoptotic cell death mediated by an excessive calcium influx (Kwak and Weiss, 2006). To test the possible protective role of truncated AMPA receptor subunits against apoptotic cell death induced by an excitotoxic stimulus, we incubated hippocampal neurons transfected with GluR1, or cotransfected with GluR1 and GluR1 $\Delta \mathrm{i} / \mathrm{o}$, with toxic concentrations of glutamate (Figs. 5A, B). Co-transfection with truncated GluR1 resulted in a significant reduction of apoptotic cell death (Fig. 5A), which was probably due to a reduction in the number of functional AMPA receptors in the plasma membrane, and which supports the hypothesis that AMPA receptors containing truncated subunits may have a neuroprotective role against excessive release of glutamate. This raised the hypothesis that the expression of truncated AMPA receptor subunits could be increased in excitotoxicity conditions and in diseases such as epilepsy, as a result of an intrinsic neuroprotective response that minimizes the damage resulting from increased neuronal activity. We consistently observed expression of the GluR1 transcript lacking the flip/flop exons in hippocampal cultures stimulated with toxic concentrations of glutamate (Fig. 5C) and expression of the GluR $3 \Delta \mathrm{i} / \mathrm{o}$ transcript in the hippocampus and cortex of epileptic rats, sacrificed 24 hours after the kainate insult (Fig. 5D). Interestingly, recent studies have found autoantibodies against GluR3 in the sera and cerebrospinal fluid of patients with severe forms of epilepsy (Mantegazza et al., 2002; Ganor et al., 2005), and these autoantibodies display glutamatergic agonist activity, which suggest that, at high concentrations and after a seizure-induced breakdown of the blood-brain barrier, excessive AMPA receptor activation by the anti-GluR3 autoantibodies might kill neurons by excitotoxicity (Cohen-Kashi Malina et al., 2006). The expression of truncated GluR3 would counteract this effect and constitute an intrinsic protective mechanism.

The mechanism of splicing that might be involved in the skipping of the flip/flop exon in AMPA receptor subunit transcripts must be studied in detail. Manipulation of the expression of these alternative splice isoforms could regulate the availability of functional AMPA receptors in situations of excessive release of glutamate, thereby preventing further losses in these situations.

\section{Experimental methods}

\section{Materials}

Dulbecco's Modified Eagle's Medium was purchased from Sigma (Madrid, Spain). Neurobasal medium, the B27 supplement and the OptiMEM I medium were purchased from Gibco Invitrogen (Paisley UK). Plasmid maxi and midiprep system were purchased from Qiagen (Germantown, USA). Trypsin was from Invitrogen-Gibco Life Technologies (Paisley, UK) and fetal calf serum was from Biowhittaker (Walkersville, MD, USA). Lipofectamine was purchased from Invitrogen (Barcelona, Spain). Anti-GFP monoclonal antibody, complete Mini protease inhibitor cocktail, high pure PCR product purification kit and microporous polyvinylidene difluoride (PVDF) membranes were purchased from Roche Diagnostics GmbH (Basel, Switzerland). First Strand cDNA Synthesis Kit for RT-PCR was purchase from Roche Applied Science (Indianapolis, IN). Quick Change Mutagenesis Kit was purchased from Stratagene Cloning Systems (Cambridge, UK). Anti-GFP polyclonal antibody was purchased from MBL International Corporation (Woburn, USA), anti-PSD 95 antibody was from Affinity BioReagents (Golden, CO) and anti-GluR1 polyclonal antibody was from Tocris Bioscience (Missouri, USA). The sheep anti-GluR1 N-terminal antibody was a kind gift from Andrew Irving (University of Dundee, Scotland). Anti-actin antibody was purchased from Roche Molecular Biochemicals (Indianapolis, IN). The alkaline phosphatase-conjugated anti-rabbit and anti-mouse secondary antibodies, and the ECF immunodetection substrate, were obtained from Amersham Biosciences (Uppsala, Sweden). Secondary fluorescent antibodies anti-rabbit Alexa 488 and Alexa 594, anti-sheep Alexa 488 and antimouse Texas Red were purchased from Molecular Probes (Leiden, The Netherlands). EZ-link Sulfo-NHS-SS-biotin and UltraLink Plus Immobilized Neutravidin Gel were purchased from Pierce (Rockford, IL, USA). pGEM-T Easy Vector was purchase from Promega (Madison, USA) and pEGFP-C1 vector from Clontech (Mountain View, USA). $\left[{ }^{3} \mathrm{H}\right]$ AMPA $(43.5 \mathrm{Ci} / \mathrm{mmol})$ was obtained from Perkin-Elmer Life Sciences (Boston, MA). All the other reagents were obtained from Sigma (St. Louis, MO, USA) or from Merck (Darmstadt, Germany).

\section{Constructs and primers}

The GluR1 $\Delta \mathrm{i} / \mathrm{o}$ (construct coding for GluR1 lacking the flip and flop exons, Figs. 1C, D) was prepared by fusion PCR, using the GluR1 construct as a template and the PCR product (551 bp) obtained from the amplification of GluR1 $\Delta \mathrm{i} / \mathrm{o}$ from rat cerebellum cDNA with primers $5^{\prime}$ GAA CCA TCC GTG TTT GTT CG 3' (Forward) and 5' TTC CTG TCT GCT CCA GTT AC 3' (Reverse).

Plasmids encoding GFP-tagged GluR1 and GFP-tagged GluR1 $\Delta \mathrm{i} / \mathrm{o}$ were prepared by inserting EGFP coding region at the N-terminus of GluR1 and GluR1 $\Delta \mathrm{i} / \mathrm{o}$, after the signal peptide. With the Quick Change Mutagenesis Kit (Stratagene Cloning Systems), an XbaI restriction site was created in the GluR1 and GluR1 $\Delta \mathrm{i} / \mathrm{o}$ constructs, using primers 5' GGT TGT GGG TGC CAA TTT TCC TCT AGA AAT ATC CAG ATA GGG G $3^{\prime}$ and 5' CCC CTA TCT GGA TAT TTC TAG AGG AAA ATT GGC ACC CAC AAC C 3'. EGFP cDNA was extracted from the pEGFP-C1 plasmid (Clontech) with $\mathrm{XbaI}$ and NheI enzymes and inserted at the $\mathrm{XbaI}$ restriction site.

GluR1(R) and GluR1 $\Delta \mathrm{i} / \mathrm{o}(\mathrm{R})$ were prepared with the Quick Change Mutagenesis Kit, using the GluR1 and GluR1 $\triangle \mathrm{i} / \mathrm{o}$ constructs as templates and primers 5' GGC CTT CAT GCG GCA AGG ATG TGATAT CTC CCC CAG GTC C 3 ' and 5' GGA CCT GGG GGA GAT ATC ACATCC TTG CCG CAT GAA GGC C 3 '.

Primers used for PCR amplification of the different rat AMPA receptor subunits were as follows: 5' GAA CCA TCC GTG TTT GTT CG 3' (GluR1 forward); 5' TTC CTG TCT GCT CCA GTT AC 3' (GluR1 reverse); 5' GAA GCC TTG TGA CAC CAT GA 3' (GluR2 forward); 5' AGC CTT GCC TTG CTC CTC AT 3' (GluR2 reverse); 5' CAA AGG CTA TGG TGT GGC AA 3' (GluR3 forward); 5' ACA CCA GGG AGA GTG AAA TC 3' (GluR3 reverse); 5' TGG AGG GCG TGG CTC GTG TC 3' (GluR4 forward); 5' TTG GGG CAG TCA GGG GTA AG 3' (GluR4 reverse). Chick GluR4 PCR primers were 5' AAA TCA GCA GAG CCG TCA G 3' (forward); 5' TTT ATG GTA GGT CCG ATG CA 3' (reverse).

\section{Isolation of total RNA}

Total RNA was isolated from rat brain or hippocampal or retinal cell cultures using the Trizol Reagent (Invitrogen). Briefly, tissue was homogenized in Trizol. After adding chloroform, the RNA was isolated in the aqueous phase. The RNA was precipitated with isopropanol, and the RNA pellet was washed with $75 \%$ ethanol and redissolved in diethylpyrocarbonate (DEPC)-treated water. The total amount of RNA was quantified by optical density measurements at $260 \mathrm{~nm}$, and the purity was evaluated by measuring the ratio of OD at 260 and $280 \mathrm{~nm}$.

\section{$R T-P C R$ and $P C R$ experiments}

Using the First Strand cDNA Synthesis Kit (Roche Applied Science), $1 \mu \mathrm{g}$ RNA was reverse transcribed into single-stranded cDNA, using avian microblastosis virus reverse transcriptase (AMV) and an Oligo-p $(\mathrm{dT})_{15}$ 
primer. RT-PCR products were then amplified with specific primers for the different subunits. Before amplification, half of the cDNA obtained was digested with RsaI (New England Biolabs) for $1 \mathrm{~h}$, at $37^{\circ} \mathrm{C}$, in order to digest the cDNA molecules containing the flip or flop regions. Polymerase chain reactions of digested and non-digested samples were performed in a $100-\mu 1$ reaction volume containing at least $1 \mu \mathrm{g}$ of template cDNA, $10 \mathrm{mM}$ of each deoxynucleotide, $20 \mu \mathrm{M}$ of each primer, 0.02 units $/ \mu 1$ Taq polymerase and the appropriate buffer, for 35 cycles of $30 \mathrm{~s}$ at $94{ }^{\circ} \mathrm{C}, 30 \mathrm{~s}$ at $57{ }^{\circ} \mathrm{C}$ (for GluR1, 2 and 3 subunits) or at $60{ }^{\circ} \mathrm{C}$ (for GluR4) and $1 \mathrm{~min}$ at $72{ }^{\circ} \mathrm{C}$. PCR products were subjected to electrophoresis in a $1.5 \%$ agarose gel and stained with ethidium bromide. Lower weight bands were isolated with high pure PCR product purification kit (Roche), cloned in pGEM-T Easy Vector (Promega) and sequenced.

\section{Cell cultures}

Human embryonic kidney (HEK 293) and kidney fibroblast (COS7) cell lines were grown in Dulbecco's modified Eagle's medium, supplemented with $10 \%$ fetal calf serum and kept at $37{ }^{\circ} \mathrm{C}$ in a humidified incubator.

Primary cultures of rat hippocampal neurons were prepared from the hippocampus of E18-E19 Wistar rat embryos. Hippocampi were dissected and dissociated with trypsin $\left(0.5 \mathrm{mg} / \mathrm{ml}, 15 \mathrm{~min}, 37^{\circ} \mathrm{C}\right)$ and deoxyribonuclease I $(0.20 \mathrm{mg} / \mathrm{ml})$, in $\mathrm{Ca}^{2+}$ and $\mathrm{Mg}^{2+}$-free Hank's balanced salt

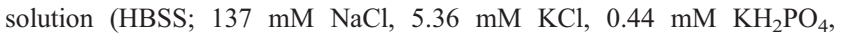
$0.34 \mathrm{mM} \mathrm{Na} \mathrm{HPO}_{4} \cdot 2 \mathrm{H}_{2} \mathrm{O}, 4.16 \mathrm{mM} \mathrm{NaHCO} 3,5 \mathrm{mM}$ glucose, supplemented with $0.001 \%$ phenol red, $1 \mathrm{mM}$ sodium pyruvate and $10 \mathrm{mM}$ HEPES, $\mathrm{pH}$ 7.4). The hippocampi were then washed in HBSS supplemented with $10 \%$ FCS in order to stop trypsin activity and mechanically dissociated in HBSS. Hippocampal cultures were maintained in Neurobasal medium, supplemented with B27 supplement, glutamate $(25 \mu \mathrm{M})$, glutamine $(0.5 \mathrm{mM})$ and gentamicin $(0.12 \mathrm{mg} / \mathrm{ml})$. The cells were kept at $37{ }^{\circ} \mathrm{C}$ in a humidified incubator of $5 \% \mathrm{CO}_{2} / 95 \%$ air. Cultures were used after 7 or 15 days in vitro (DIV).

Primary cultures of chick retina amacrine-like neurons were prepared as previously described (Duarte et al., 1996; Gomes et al., 2004). Briefly, the retinas from 8-day-old chick embryos (White Leghorn) were dissected and digested with $0.1 \%$ trypsin, in $\mathrm{Ca}^{2+}$ - and $\mathrm{Mg}^{2+}$-free Hank's balanced salt solution for $15 \mathrm{~min}$ at $37^{\circ} \mathrm{C}$. The cells were cultured on poly-D-lysine tissue culture dishes in basal medium of Eagle (BME), buffered with $25 \mathrm{mM}$ HEPES and $10 \mathrm{mM} \mathrm{NaHCO}$, pH 7.4, and supplemented with $5 \%$ heatinactivated fetal calf serum, penicillin $(100 \mathrm{U} / \mathrm{ml})$, and streptomycin $(100 \mu \mathrm{g} / \mathrm{ml})$. The cells were maintained at $37^{\circ} \mathrm{C}$ in a humidified incubator with $95 \%$ air and $5 \% \mathrm{CO}_{2}$, and used after 5 DIV.

\section{Transfection experiments}

HEK 293 cells were transiently transfected (Carvalho et al., 1999) by calcium phosphate precipitation with $2 \mu \mathrm{g}$ of DNA per well in a six-well plate. Cells were washed twice with fresh medium, $8 \mathrm{~h}$ after the addition of DNA/calcium phosphate precipitate. Experimental treatments started $48 \mathrm{~h}$ after transfection. COS7 cells were transfected using lipofectamine reagent. Each well of a six-well plate was loaded with $250 \mu \mathrm{l}$ of Opti-MEM solution containing $2 \mu \mathrm{g}$ of DNA and $12.5 \mu \mathrm{l}$ of lipofectamine reagent, and incubated for $5 \mathrm{~h}$. The cells were used $48 \mathrm{~h}$ after transfection.

Hippocampal neurons were transiently transfected at 5 DIV or 14 DIV using a calcium phosphate co-precipitation protocol (Jiang et al., 2004). Cells were cultured at a density of $45 \times 10^{3}$ cells $/ \mathrm{cm}^{2}$. The DNA/calcium phosphate precipitate was prepared by mixing one volume of DNA (diluted in $1 \times \mathrm{TE} \mathrm{pH} 7.3$ in $2.5 \mathrm{M} \mathrm{CaCl}_{2}$ in $10 \mathrm{mM}$ HEPES) with an equal volume of $2 \times$ HeBS solution (274 mM NaCl, $10 \mathrm{mM} \mathrm{KCl}, 1.4 \mathrm{mM} \mathrm{Na} 2 \mathrm{HPO}_{4}$, $15 \mathrm{mM}$ D-glucose, $42 \mathrm{mM}$ HEPES, $\mathrm{pH}$ 7.2). For each well of a 24- or 12well plate, the amount of DNA used was $2 \mu \mathrm{g}$ or $4 \mu \mathrm{g}$, respectively. The precipitate was let to form for $30 \mathrm{~min}$ at room temperature, vortexing every $5 \mathrm{~min}$. While the precipitate was developing, coverslips were transferred to new wells containing $200 \mu \mathrm{l}$ of conditioned medium and kynurenic acid
$10 \mathrm{mM}$. After the addition of the precipitates, cells were returned to the incubator for another $3 \mathrm{~h}$. Each coverslip was then transferred to a fresh well containing $1 \mathrm{ml}$ of $10 \% \mathrm{CO}_{2}$ equilibrated (acidic) glutamate-free Neurobasal Medium (MNB), containing $2 \mathrm{mM}$ kynurenic acid, and returned to the incubator for another $15 \mathrm{~min}$. Neurons were then returned to the original wells containing the conditioned medium.

\section{Biotinylation and purification of plasma membrane-associated proteins}

Cells were washed twice with phosphate-buffered saline (PBS) with calcium and magnesium (PBS/ $\mathrm{Ca}^{2+} / \mathrm{Mg}^{2+}: 137 \mathrm{mM} \mathrm{NaCl} ; 2.7 \mathrm{mM} \mathrm{KCl}$; $1.8 \mathrm{mM} \mathrm{KH}_{2} \mathrm{PO}_{4} ; 10 \mathrm{mM} \mathrm{Na}_{2} \mathrm{HPO}_{4}$; plus $0.5 \mathrm{mM} \mathrm{MgCl}_{2} ; 1 \mathrm{mM} \mathrm{CaCl}$; $\mathrm{pH}$ 7.4), and then incubated with $1 \mathrm{mg} / \mathrm{ml} \mathrm{NHS-SS-Biotin} \mathrm{for} 30 \mathrm{~min}$ at $4{ }^{\circ} \mathrm{C}$ under mild shaking. Cells were then washed twice with $\mathrm{PBS} / \mathrm{Ca}^{2+} / \mathrm{Mg}^{2+}$ supplemented with glycine $(100 \mathrm{mM})$ and incubated in the same solution for 45 min. Cells were lysed with RIPA buffer supplemented with protease and phosphatase inhibitors, scraped off the plates, sonicated for $30 \mathrm{~s}$ on ice and centrifuged at $14,000 \mathrm{rpm}$ for $10 \mathrm{~min}$ at $4{ }^{\circ} \mathrm{C}$. The supernatant fluids were transferred to clean tubes. NeutrAvidin beads (Pierce) were added to equal amounts of supernatant fluid $(2 \mu \mathrm{l} / 10 \mu \mathrm{g}$ total protein) and incubated for $2 \mathrm{~h}$ at $4{ }^{\circ} \mathrm{C}$ with mild shaking (orbital shaker). The beads were washed four times with RIPA buffer by centrifugation $(2500 \times \mathrm{g}, 3 \mathrm{~min})$. The samples were eluted with sample buffer (100 mM Tris, $100 \mathrm{mM}$ glycine, 4\% SDS, $8 \%$ $\beta$-mercaptoethanol, $8 \mathrm{M}$ urea and $1.5 \mathrm{mM}$ sodium orthovanadate) and centrifuged into a tube collector with filter.

\section{SDS-PAGE and Immunoblotting}

The extracts obtained were resolved by SDS-PAGE in $10 \%$ polyacrylamide gels. This was followed by overnight electrotransfer to PVDF membranes, at $40 \mathrm{~V}$, complemented by $30 \mathrm{~min}$ at $200 \mathrm{~V}$, at room temperature. Membranes were then blocked for $1 \mathrm{~h}$ at room temperature, in Tris-buffered saline (137 mM NaCl, $20 \mathrm{mM}$ Tris- $\mathrm{HCl}, \mathrm{pH}$ 7.6) containing $0.1 \%(\mathrm{v} / \mathrm{v})$ Tween $20(\mathrm{TBS}-\mathrm{T})$ and $5 \%(\mathrm{w} / \mathrm{v})$ low-fat milk, and probed for $1 \mathrm{~h}$ with the primary antibodies (anti-GFP 1:1000, anti-GluR1 C-terminal 1:500 and anti-GluR1 N-terminal 1:750) diluted in TBS-T containing $0.5 \%$ low-fat milk at room temperature. Following five washes (5 min) in TBS-T, the membranes were incubated for $1 \mathrm{~h}$ with the respective alkaline phosphatase-conjugated secondary antibodies (anti-mouse and anti-rabbit 1:20000 and anti-sheep 1:10000). The membranes were then washed again five times $(5 \mathrm{~min})$, incubated with chemifluorescence substrate (ECF) for 5 min, and scanned with the Storm 860 scanner (Amersham Biosciences). Where indicated the membranes were stripped and reprobed with mouse anti-actin antibody (1:10000).

\section{Stimuli}

For cell viability experiments, hippocampal neurons in culture (6 DIV) were incubated with $125 \mu \mathrm{M}$ glutamate in supplemented Neurobasal medium, for $20 \mathrm{~min}$ at $37^{\circ} \mathrm{C}$, in a humidified incubator. After stimulation with glutamate, the cells were further incubated with the original culture medium, for $14 \mathrm{~h}$ at $37^{\circ} \mathrm{C}$. For mRNA isolation, hippocampal cells (14 DIV) were incubated with $150 \mu \mathrm{M}$ glutamate in supplemented Neurobasal medium, for $20 \mathrm{~min}$ at $37^{\circ} \mathrm{C}$, in a humidified incubator. After stimulation with glutamate, the cells were further incubated with original culture medium, for 2 to $4 \mathrm{~h}$ at $37^{\circ} \mathrm{C}$.

\section{Cell viability}

Cell viability was measured after fixing the cells in $4 \%$ paraformaldehyde and $4 \%$ sucrose for $10 \mathrm{~min}$ at room temperature. Fixed cells were washed with phosphate-buffered saline (PBS) and stained with the fluorescent dye Hoechst $33342(0.5 \mu \mathrm{g} / \mathrm{ml})$. The coverslips were mounted 
on glass slides and examined under a Zeiss Axiovert 200 fluorescence microscope.

\section{Immunostaining}

Hippocampal cells were fixed in $4 \%$ paraformaldehyde and $4 \%$ sucrose for $10 \mathrm{~min}$ at room temperature and then incubated with $0.2 \%$ gelatine in PBS-T (PBS with $0.1 \%$ Tween) for $1 \mathrm{~h}$, at room temperature. For double labeling of neurons for receptors tagged with GFP and for PDS 95, the cells were incubated with monoclonal antibodies anti-GFP (1:200) and anti-PSD 95 (1:200). After $1 \mathrm{~h}$ incubation, cells were washed with PBS-T with $0.1 \%$ gelatine, for $5 \mathrm{~min}$, and incubated with secondary antibodies anti-rabbit Alexa 488 (1:500) and anti-mouse Texas-Red (1:1000) for $1 \mathrm{~h}$. To detect surface expression, transfected neurons were labeled in vivo with anti-GFP antibody $(1: 200)$ and COS7 cells with anti-GluR1 N-terminal antibody (1:200) for $20 \mathrm{~min}$ at $4{ }^{\circ} \mathrm{C}$, washed two times with PBS and then fixed and incubated with $0.2 \%$ gelatine in PBS-T for $1 \mathrm{~h}$, at room temperature. After washing with $0.1 \%$ gelatine PBS-T, cells were incubated with secondary antibodies anti-rabbit Alexa 594 (1:200) and anti-sheep Alexa 488 (1:200), respectively. The coverslips were mounted on glass slides and examined under a Zeiss Axiovert 200 fluorescence microscope, coupled to an Axion Cam HZM camera.

\section{Co-immunoprecipitation assay}

Co-precipitation experiments were preformed as previously described by Ayalon and Stern-Bach (2001). Briefly, 24 to $48 \mathrm{~h}$ after transfection, COS7 cells were washed with warm PBS, scraped, collected and homogenized in ice-cold solubilization buffer $(20 \mathrm{mM}$ Tris- $\mathrm{HCl}, \mathrm{pH} 8.0$, $100 \mathrm{mM} \mathrm{NaCl}, 1 \%$ Triton X-100, $0.05 \%$ SDS) in the presence of a cocktail of protease inhibitors (Complete mini). Clear supernatants were incubated with protein A sepharose and anti-GluR1 C-terminus, anti-GluR1 Nterminus or anti-GFP antibodies for $4 \mathrm{~h}$ at $4{ }^{\circ} \mathrm{C}$ with shaking. Beads were then washed twice with $1 \mathrm{ml}$ ice-cold solubilization buffer. Bound proteins were released by $5 \mathrm{~min}$ boiling with SDS-PAGE loading buffer and collected after a short centrifugation. Western blot analysis was performed as described above.

\section{Electrophysiology}

Glutamate-induced responses were recorded from HEK 293 cells 24 to $48 \mathrm{~h}$ after transfection, under the whole-cell configuration of the patch clamp technique. The internal pipette solution was $120 \mathrm{mM}$ CsMeSO, $10 \mathrm{mM}$ EGTA, $0.5 \mathrm{mM} \mathrm{CaCl}_{2}, 5 \mathrm{mM} \mathrm{MgCl}_{2}, 15 \mathrm{mM} \mathrm{CsCl}$, and $10 \mathrm{mM}$ HEPES, $\mathrm{pH} 7.3$ and the external solution consisted of (in $\mathrm{mM}$ ) $\mathrm{NaCl} 120$, $\mathrm{KCl} 2.5, \mathrm{CaCl}_{2}$ 1.8, $\mathrm{MgCl}_{2}$ 2, glucose 10 and HEPES 10 (pH 7.3). Cells were rapidly perfused as described previously (Rozas et al., 2003). Data analysis was done with pCLAMP software (AXON Instruments). Experiments were carried out at room temperature $\left(22-25^{\circ} \mathrm{C}\right)$.

\section{Binding assays}

HEK 293 cells were transfected as described above. After being washed with PBS, cells were scraped and centrifuged at $14,000 \times \mathrm{g}$ for $5 \mathrm{~min}$ at $4{ }^{\circ} \mathrm{C}$. The pellet was frozen at $-20^{\circ} \mathrm{C}$ for at least $2 \mathrm{~h}$, and was resuspended in water with protease inhibitors, at $4{ }^{\circ} \mathrm{C}$. Cell membranes were obtained by sedimentation of the lysate at $50,000 \times \mathrm{g}$ for $15 \mathrm{~min}$ at $4{ }^{\circ} \mathrm{C}$. The membrane pellet was then resuspended in $50 \mathrm{mM}$ Tris $-\mathrm{HCl}(\mathrm{pH} 7.5)$, followed by protein quantification with the BCA method.

The $\left[{ }^{3} \mathrm{H}\right] \mathrm{AMPA}$ binding assays were performed with $500 \mu \mathrm{g}$ of protein in $50 \mathrm{mM}$ Tris- $\mathrm{HCl}(\mathrm{pH} 7.5$ ) supplemented with $0.3 \mathrm{M} \mathrm{KSCN}$, and different concentrations of $\left[{ }^{3} \mathrm{H}\right]$ AMPA $(1-300 \mathrm{nM})$, in the absence (total binding) or presence of $1 \mathrm{mM}$ glutamate (nondisplaceable binding). Incubations were performed for $1 \mathrm{~h}$ at $4{ }^{\circ} \mathrm{C}$ and ligand binding was stopped by filtration through pre-washed Whatman GF/C filters (Whatman, Middlesex, UK). Filters were then washed rapidly three times, with icecold $50 \mathrm{mM}$ Tris- $\mathrm{HCl}, \mathrm{pH} 7.4$, supplemented by $0.1 \mathrm{M} \mathrm{KSCN}$. The filters were incubated in a scintillation cocktail containing 2,5-diphenyloxazol (PPO) $(5.84 \mathrm{~g} / \mathrm{l})$ and 1,4-bis (5-phenyl-2-oxazolyl) benzene (POPOP) $(133.6 \mathrm{mg} / \mathrm{l})$, in a $4: 1 \mathrm{mixture}$ of toluol and triton X-100, for at least $8 \mathrm{~h}$, before measuring the radioactivity in a Packard 2000 Spectrometer provided with dpm correction.

\section{Kainate treatment}

Samples from epileptic rats were kindly provided by Ana Paula Silva and João Malva (Center for Neuroscience and Cell Biology, University of Coimbra, Portugal). Male 6-week-old Wistar rats (150-200 g) were injected intraperitoneally with kainic acid (KA) (Sigma, St. Louis, MO, USA; $10 \mathrm{mg} / \mathrm{kg}$ body weight) in a maximum volume of $500 \mu \mathrm{l}$ sterile $0.9 \% \mathrm{NaCl}$. All the animals used in the present study achieved status epilepticus and were killed $24 \mathrm{~h}$ after KA injection.

\section{Statistical analysis}

Results are presented as average \pm S.E.M. of the indicated number of experiments, carried out in different preparations. Results were analyzed using one-way ANOVA, followed by Bonferroni's Multiple Comparison Test, or using the Student's $t$ test.

\section{Acknowledgments}

The authors would like to thank João Malva and Ana Paula Silva (Center for Neuroscience and Cell Biology, University of Coimbra, Portugal) for the epileptic rat brain samples and Andrew Irving (University of Dundee, Scotland) for the antibody against the N-terminus of GluR1. We also thank Elisabete Carvalho for assistance in the preparation of hippocampal neuron cultures.

This work was supported by Fundação para a Ciência e a Tecnologia, Portugal (SFRH/BD/1286/2000, POCTI/BCI/39127/ 2001 and POCI/SAU-NEU/58955/2004) and the BFU2006-07138 grant to JL.

\section{References}

Ayalon, G., Stern-Bach, Y., 2001. Functional assembly of AMPA and kainate receptors is mediated by several discrete protein-protein interactions. Neuron 31, 103-113.

Barbon, A., Vallini, I., Barlati, S., 2001. Genomic organization of the human GRIK2 gene and evidence for multiple splicing variants. Gene 274, $187-197$.

Bredt, D.S., Nicoll, RA., 2003. AMPA receptor trafficking at excitatory synapses. Neuron 40, 361-379.

Carvalho, A.L., Kameyama, K., Huganir, R.L., 1999. Characterization of phosphorylation sites on the glutamate receptor 4 subunit of the AMPA receptors. J. Neurosci. 19, 4748-4754.

Carvalho, A.L., Duarte, C.B., Carvalho, A.P., 2000. Regulation of AMPA receptors by phosphorylation. Neurochem. Res. 25, 1245-1255.

Cohen-Kashi Malina, K., Ganor, Y., Levite, M., Teichberg, V.I., 2006. Autoantibodies against an extracellular peptide of the GluR3 subtype of AMPA receptors activate both homomeric and heteromeric AMPA receptor channels. Neurochem. Res. 31, 1181-1190.

Conti, E., Izaurralde, E., 2005. Nonsense-mediated mRNA decay: molecular insights and mechanistic variations across species. Curr. Opin. Cell Biol. 17, 316-325.

Duarte, C.B., Santos, P.F., Carvalho, A.P., 1996. $\left[\mathrm{Ca}^{2+}\right]_{\mathrm{i}}$ regulation by glutamate receptor agonists in cultured chick retina cells. Vision Res. 36, 1091-1102. 
Fujikawa, D.G., 2005. Prolonged seizures and cellular injury: understanding the connection. Epilepsy Behav. 7 (Suppl 3), S3-S11.

Ganor, Y., Goldberg-Stern, H., Lerman-Sagie, T., Teichberg, V.I., Levite, M., 2005. Autoimmune epilepsy: distinct subpopulations of epilepsy patients harbor serum autoantibodies to either glutamate/AMPA receptor GluR3, glutamate/NMDA receptor subunit NR2A or double-stranded DNA. Epilepsy Res. 65, 11-22.

Gomes, A.R., Correia, S.S., Carvalho, A.L., Duarte, C.B., 2003. Regulation of AMPA receptor activity, synaptic targeting and recycling: role in synaptic plasticity. Neurochem. Res. 28, 1459-1473.

Gomes, A.R., Cunha, P., Nuriya, M., Faro, C.J., Huganir, R.L., Pires, E.V., Carvalho, A.L., Duarte, C.B., 2004. Metabotropic glutamate and dopamine receptors co-regulate AMPA receptor activity through PKA in cultured chick retinal neurones: effect on GluR4 phosphorylation and surface expression. J. Neurochem. 90, 673-682.

Grabowski, P.J., Black, D.L., 2001. Alternative RNA splicing in the nervous system. Prog. Neurobiol. 65, 289-308.

Greger, I.H., Akamine, P., Khatri, L., Ziff, E.B., 2006. Developmentally regulated, combinatorial RNA processing modulates AMPA receptor biogenesis. Neuron 51, 85-97.

Hollmann, M., Heinemann, S., 1994. Cloned glutamate receptors. Annu. Rev. Neurosci. 17, 31-108.

Hollmann, M., Maron, C., Heinemann, S., 1994. N-glycosylation site tagging suggests a three transmembrane domain topology for the glutamate receptor GluR1. Neuron 13, 1331-1343.

Jiang, M., Deng, L., Chen, G., 2004. High Ca(2+)-phosphate transfection efficiency enables single neuron gene analysis. Gene Ther. 11, 1303-1311.

Kwak, S., Weiss, J.H., 2006. Calcium-permeable AMPA channels in neurodegenerative disease and ischemia. Curr. Opin. Neurobiol. 16, 281-287.

Leuschner, W.D., Hoch, W., 1999. Subtype-specific assembly of alpha-amino3-hydroxy-5-methyl-4-isoxazole propionic acid receptor subunits is mediated by their N-terminal domains. J. Biol. Chem. 274, 16907-16916.

Lipscombe, D., 2005. Neuronal proteins custom designed by alternative splicing. Curr. Opin. Neurobiol. 15, 358-363.

Luscher, C., Nicoll, R.A., Malenka, R.C., Muller, D., 2000. Synaptic plasticity and dynamic modulation of the postsynaptic membrane. Nat. Neurosci. 3, 545-550.

Madden, D.R., 2002. The structure and function of glutamate receptor ion channels. Nat. Rev., Neurosci. 3, 91-101.

Malenka, R.C., Bear, M.F., 2004. LTP and LTD: an embarrassment of riches. Neuron 44, 5-21.

Malinow, R., Malenka, R.C., 2002. AMPA receptor trafficking and synaptic plasticity. Annu. Rev. Neurosci. 25, 103-126.
Malinow, R., Mainen, Z.F., Hayashi, Y., 2000. LTP mechanisms: from silence to four-lane traffic. Curr. Opin. Neurobiol. 10, 352-357.

Mantegazza, R., Bernasconi, P., Baggi, F., Spreafico, R., Ragona, F., Antozzi, C., Bernardi, G., Granata, T., 2002. Antibodies against GluR3 peptides are not specific for Rasmussen's encephalitis but are also present in epilepsy patients with severe, early onset disease and intractable seizures. J. Neuroimmunol. 131, 179-185.

Modrek, B., Lee, C., 2002. A genomic view of alternative splicing. Nat Genet. 30, 13-19.

Monyer, H., Seeburg, P.H., Wisden, W., 1991. Glutamate-operated channels: developmentally early and mature forms arise by alternative splicing. Neuron 6, 799-810.

Mosbacher, J., Schoepfer, R., Monyer, H., Burnashev, N., Seeburg, P.H., Ruppersberg, J.P., 1994. A molecular determinant for submillisecond desensitization in glutamate receptors. Science 266, 1059-1062.

Mu, Y., Otsuka, T., Horton, A.C., Scott, D.B., Ehlers, M.D., 2003. Activitydependent mRNA splicing controls ER export and synaptic delivery of NMDA receptors. Neuron 40, 581-594.

O’Brien, R.J., Lau, L.F., Huganir, R.L., 1998. Molecular mechanisms of glutamate receptor clustering at excitatory synapses. Curr. Opin. Neurobiol. 8, 364-369.

Ozawa, S., Kamiya, H., Tsuzuki, K., 1998. Glutamate receptors in the mammalian central nervous system. Prog. Neurobiol. 54, 581-618.

Ravindranathan, A., Parks, T.N., Rao, M.S., 1997. New isoforms of the chick glutamate receptor subunit GluR4: molecular cloning, regional expression and developmental analysis. Brain Res. Mol. Brain Res. 50, $143-153$

Rozas, J.L., Paternain, A.V., Lerma, J., 2003. Noncanonical signaling by ionotropic kainate receptors. Neuron 39, 543-553.

Ruberti, F., Dotti, C.G., 2000. Involvement of the proximal C terminus of the AMPA receptor subunit GluR1 in dendritic sorting. J. Neurosci. 20, RC78.

Rumbaugh, G., Sia, G.M., Garner, C.C., Huganir, R.L., 2003. Synapseassociated protein-97 isoform-specific regulation of surface AMPA receptors and synaptic function in cultured neurons. J. Neurosci. 23, 4567-4576.

Sommer, B., Keinanen, K., Verdoorn, T.A., Wisden, W., Burnashev, N., Herb, A., Kohler, M., Takagi, T., Sakmann, B., Seeburg, P.H., 1990. Flip and flop: a cell-specific functional switch in glutamate-operated channels of the CNS. Science 249, 1580-1585.

Verdoorn, T.A., Burnashev, N., Monyer, H., Seeburg, P.H., Sakmann, B., 1991. Structural determinants of ion flow through recombinant glutamate receptor channels. Science 252, 1715-1718.

Wells, G.B., Lin, L., Jeanclos, E.M., Anand, R., 2001. Assembly and ligand binding properties of the water-soluble extracellular domains of the glutamate receptor 1 subunit. J. Biol. Chem. 276, 3031-3036. 